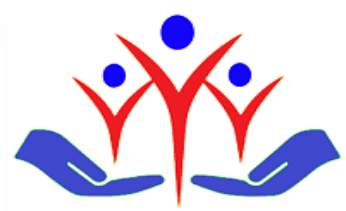

Research Article

\title{
Evaluation of children with acute gastroenteritis in Konya region
}

\author{
Konya yöresindeki akut gastroenteritli çocukların değerlendirilmesi
}

\author{
Ahmet Osman Kilic a (D) Hussein M.H. Atwan ${ }^{\mathrm{a}}$, (D) Abdullah Yazar ${ }^{\mathrm{a}}$ (iD) Fatih Akin ${ }^{\mathrm{a}}$ \\ a Department of Pediatrics, Meram Faculty of Medicine, Necmettin Erbakan University, Konya, Turkey
}

\begin{abstract}
Introduction: Acute gastroenteritis is a major cause of pediatric morbidity and mortality around the world. It remains a frequent reason for infection-related admissions to emergency units among all age groups. Epidemiologic knowledge about etiology of gastroenteritis in a certain area allows early and correct diagnosis. The current study aimed at evaluating the prevalence of bacterial, viral, and parasitic pathogens in children with gastroenteritis who admitted to pediatric emergency unit.

Methods: The demographic, clinical and laboratory data of 450 children with acute gastroenteritis, within the age range of 0 months to 18 years who admitted to Pediatric Emergency Department of Meram Faculty of Medicine from September 2018 to September 2019 were retrospectively analyzed.

Results: While $31.10 \%$ of the patients had etiological agents, $68.90 \%$ of the patients could not be identified. The identified pathogens were $2.10 \%$ bacteria, $82.20 \%$ virus, $15.70 \%$ parasite. The most common pathogen was Rotavirus with a rate of $72.90 \%$. This was followed by E. histolytica with $15.00 \%$ and Adenovirus with $9.30 \%$. Rotavirus was most frequently detected at the age of 2 years, and E. histolytica was most frequently detected at the age of 5 years. Rotavirus was most common in the winter season [33.7\%]. $7.10 \%$ of the patients were hospitalized. The average length of hospital stay was $3.34 \pm 2.19$ days.

Conclusion: Rotavirus, E. histolytica and Adenovirus were the most prevalent agents of diarrhea in children aged 0 month to 18 years who admitted to emergency unit in this study.
\end{abstract}

Keywords: Children, Gastroenteritis, Pediatric emergency department

$\ddot{O} z$

Giriş:Akut gastroenterit dünya çapında çocukluk çağında morbidite ve mortalitenin önemli bir nedenidir. Tüm yaş grupları arasında acil servislere yapılan başvuruların sık görülen bir nedeni olmaya devam etmektedir. Bulunulan bölgedeki gastroenterit etkenlerinin bilinmesi, erken ve doğru tanı, etkin tedavi firsatı sağlayacaktır. Bu çalışma Konya bölgesinde, çocuk acil servisinde gastroenterit tanısı alan çocuklarda bakteriyel, viral ve parazitik patojenlerin prevalansını değerlendirmeyi amaçlamıştır.

Yöntem: Eylül 2018-Eylül 2019 tarihleri arasında Meram Tıp Fakültesi Hastanesi Çocuk Acil Servisinde akut gastroenterit tanısı alan 0 ay ile 18 yaş arasındaki 450 akut çocuğun demografik, klinik ve laboratuvar verileri retrospektif olarak incelendi.

Bulgular: Hastaların \%31,10'unda etiyolojik ajanlar bulunurken, hastaların \%68,90'nda ajanlar gösterilemedi. Belirlenen patojenler 2,10'u bakteri, $\% 82,20$ virüs,\%15,70 parazit idi. En s1k saptanan patojen \%72,90 oranı ile Rotavirus'tu. Bunu \%15,00 ile E. histolytica ve \%9,30 ile Adenovirus izledi. Rotavirus en sik ilk 2 yaşta, E. histolytica ise en sık 5 yaş üzerinde tespit edildi. Rotavirus en sık kış mevsiminde [\%33,70] görüldü. Hastaların \%7,10’u hastanede yatarak tedavi edildi. Ortalama hastanede yatış süresi 3,34 $\pm 2,19$ gün idi.

Sonuç: Bu çalışmada Rotavirus, E. histolytica ve Adenovirus acil servise başvuran 0 ay ile 18 yaş arasındaki çocuklarda en yaygın gastroenterit etkenleridir.

Anahtar kelimeler: Çocuklar, Çocuk Acil Servis, Gastroenterit

\begin{tabular}{|c|c|c|c|c|}
\hline Received & Accepted & Published Online & Corresponding Author & E-mail \\
\hline June 2, 2020 & December 23, 2020 & March 31, 2021 & Ahmet Osman Kilic, MD & drahmetosmankilic@ gmail.com \\
\hline Correspondence & $\begin{array}{l}\text { Dr. Necmettin Erbakan Üniversitesi Meram Tıp Fakültesi Çocuk Sağlığ1 ve Hastalıkları AD } \\
\text { 42080 Meram/Konya, Turkey }\end{array}$ \\
\hline
\end{tabular}




\section{Introduction}

Acute gastroenteritis [AGE] refers to the inflammation of the gastrointestinal tract with bacterial, viral or parasitic pathogens [1]. Acute gastroenteritis is one of the important diseases of childhood leading to morbidity and mortality [2]. This disease can lead to dehydration, hypovolemic shock and death in severe cases. It caused 1.3 million deaths worldwide in 2015 and ranks fourth among causes of death among children under 5 years of age with an average of 499 thousand deaths per year [3]. Acute gastroenteritis is also important for the negative effects of malnutrition and growth-development in children.

Factors such as environmental conditions, socioeconomic status pose a risk for AGE. Diseases with acute diarrhea mostly occur due to infectious causes. Viruses are the most common agents among gastroenteritis agents, followed by bacteria and parasites. Rotavirus is the most common infectious agent causing gastroenteritis in children [1]. Among the bacteria, Campylobacter jejuni, Escherichia coli [E.coli], non-typhoidal Salmonella spp. and Shigellae spp. are common agents [4].

Cases of acute gastroenteritis can occur sporadically or in the form of outbreaks. In addition to the virulence of agents, various factors such as age, nutritional status, and immune status of the host are also effective in the presentation of the disease. Gastroenteritis agents vary according to regions and seasons. While the factors that can be described as classical are common in developing and crowded populations, technological developments may play a role in the occurrence of some microorganisms as pathogens more frequently [4].

Acute gastroenteritis is mostly self-limited. The developing technology has enabled the determination of the virulence factors of the agents and revealing the physiopathology of the disease. In this way, significant improvements have been achieved in treatment. However, treatment becomes more and more difficult as pathogenic microorganisms become more and more resistant to more antimicrobial drugs. Empirical use of antibiotics is common practice in the treatment of AGE, and unnecessary use of antibiotics can lead to an increase in treatment cost and antibiotic resistance in microorganisms. Therefore, it is important to determine the effect correctly and to give the appropriate treatment. It is important to know possible regional and seasonal gastroenteritis agents for correct diagnosis and effective treatment.

In this study, it was aimed to determine the agents in children who applied with acute gastroenteritis in our region, the seasonal distribution of these factors and to evaluate the relationships between the factors and laboratory investigations.

\section{Methods}

The data of patients between 0-18 years old who were admitted to Necmettin Erbakan University Meram Medical Faculty Child Emergency Clinic between September 2018 and September 2019 and diagnosed with gastroenteritis were analyzed retrospectively. In the pediatric emergency room, 450 patients who were treated with the code A09 and K52 in the ICD coding, stool culture, stool microscopy examination or Adenovirus and Rotavirus antigen test in the stool were included in the study. Patients with chronic diarrhea and no examination for the agent were not included in the study.

Patients' age, gender, hospital admission dates were recorded. Age, month and year were evaluated separately. 0-1 months of newborn period, 112 months of infancy, 1-3 years of childhood of childhood, 4-6 years of preschool childhood, 6-11 years of school childhood, 12-18 years of adolescence [5].

Leukocyte Count [LC], Absolute Neutrophil Count [ANC], Absolute Lymphocyte Count [ALC], Platelet Count [PC], Urea, Creatinine, Sodium, Potassium, Aspartate Aminotransferase [AST], Alanine Aminotransferase [ALT], Erythrocyte Sedimentation Rate [ESR], C Reactive Protein [CRP], serum Glucose tests were examined.

\section{Ethical Approval}

This study was done with the approval of Necmettin Erbakan University Meram Medical Faculty Ethics Committee. Decision number: [2019/2045]

\section{Statistical Analysis}

Data analysis was performed with SPSS [statistic package for social sciences, Chicago, IL, USA] 22.0 package program. Descriptive statistics were presented as mean \pm standard deviation for continuous variables and as number and percentage for categorical variables. The Shapiro Wilk test evaluated whether the distribution of continuous variables was close to normal. In cases where the data did not show normal distribution, Kruskal Wallis test was used in binary groups and Wilcoxon test was used in 3 or more groups. In case of a difference between the groups, which groups the difference was caused by Pairwise comparison. Chi-square test was used to compare categorical data. $p<0.05$ values were considered significant.

\section{Results}

Four hundred and fifty patients were included in the study. The median age of the patients was 21 months [1-170 months]. 48.20\% [217/450] of the patients were male and 51.8\% [233/450] were female. Two [0.40\%] of the patients included in the study were in the neonatal period, 108 [24\%] were in the infancy period, 192 [42.67\%] were in the play age period, 54 [12\%] were in the pre-school period. 56 [12.40\%] were in school childhood and $38[8.40 \%]$ were in adolescence. 
Seventy-nine [17.60\%] of the applications were from year 2018, 371 [82.40\%] were from 2019. The distribution of the applications according to the seasons was $35.33 \%$ autumn, $26 \%$ summer, $19.78 \%$ winter, $18.89 \%$ spring. Considering the distribution of the cases according to the seasons, the number of applications made in the autumn was statistically significantly higher than the other seasons [p <0.001]

While $32[7.10 \%]$ of the patients were treated inpatient, 418 [92.90\%] patients were treated outpatient. The mean length of hospital stay in inpatients was $3.34 \pm 2.19$ days. The distribution of application complaints is given in table 1 .

Table 1.Distribution of symptoms

\begin{tabular}{lcc}
\hline Symptom & $\mathrm{n}$ & $\%$ \\
\hline Diarrhea & 423 & 94.00 \\
Vomiting & 247 & 54.90 \\
Fever & 140 & 31.10 \\
Abdominal pain & 55 & 12.20 \\
Seizure & 2 & 0.40 \\
\hline
\end{tabular}

Data are shown as number of patients [n] and percent [\%]

Stool culture was examined in 81 of 450 patients included in the study. Parasite examination and Rotavirus and Adenovirus antigen tests in the stool were studied in all patients included in the study. No agent that could cause disease was detected in $68.90 \%$ [310/450] of the examinations. The distribution of the detected agents is shown in table 2 . In the examinations, the rates of undetectable agent were statistically significantly higher than the rate of detectability [p $<0.001]$. When looking at the distribution of agents, viruses were found to be statistically significantly more frequent than bacteria and parasites $[\mathrm{p}<0.001]$. Rotavirus was found to be statistically significantly more common among other detected microorganisms $[\mathrm{p}<0.001]$.

Table 2. Distribution of agent groups

\begin{tabular}{lcc}
\hline Agent Groups & n & \% \\
\hline Bacterium & 3 & 2.10 \\
E.coli & 1 & 0.70 \\
Klebsiella spp & 1 & 0.70 \\
Salmonella spp & 1 & 0.70 \\
Parasite & 22 & 15.70 \\
E. histolytica & 21 & 15 \\
Cryptosporidium & 1 & 0.70 \\
Virus & 115 & 82.20 \\
Rotavirus & 102 & 72.80 \\
Adenovirus & 13 & 9.20 \\
\hline
\end{tabular}

Data are shown as number of patients [n] and percent [\%]

The median age was 32 [3-79] months in patients with Adenovirus, 69 [2-104] months in patients with E. histolytica, 17 [0-157] months in patients with Rotavirus, and 29 [1-208] months in patients in whom the factor was not detected. . 66.70\% of patients with rotavirus were under 2 years old. $90.50 \%$ of the patients in which the factor was E. histolytica were patients older than 2 years. Adenovirus was detected in patients younger than two years, $46.20 \%$ and older than two years, $53.80 \%$.

Considering the distribution of agents according to the seasons, Adenovirus was detected at a lower rate in the spring, while E. histolytica was detected at a lower rate in the winter and Rotavirus in the summer. While seasonal difference was not statistically significant for adenovirus and E. histolytica [p: 0.442 and p: 0.165], seasonal difference in rotavirus was significant [p: 0.042]. In the winter months, it was found that the patients whose agent could not be determined compared to the summer months were seen more frequently [p $<0.001]$.

In Table 3, the average values of the patients' examination results are indicated. There were no statistically significant differences between the microorganisms and WBC, ANC, ALC, CRP results [p: 0.065, p: 0.508, p: 0.908, p: 0.564, respectively] 
Table 3. Blood examination results

\begin{tabular}{lcc} 
& n & Mean \pm SD \\
\hline WBC $\left[10^{\wedge} 3 / \mathrm{uL}\right]$ & 262 & $11.72 \pm 69.82$ \\
ANC $\left[10^{\wedge} 3 / \mathrm{uL}\right]$ & 262 & $7.09 \pm 8.16$ \\
ALC [10^3/uL] & 262 & $3.70 \pm 2.51$ \\
PC [10^3/uL] & 262 & $311.00 \pm 97.00$ \\
Urea [mg/dL] & 270 & $31.85 \pm 115.76$ \\
Creatinine [mg/dL] & 270 & $0.46 \pm 0.16$ \\
Sodium [mmol/L] & 270 & $134.15 \pm 18.59$ \\
Potassium [mmol/L] & 270 & $4.41 \pm 2.76$ \\
AST [U/L] & 269 & $33.49 \pm 21.84$ \\
ALT [U/L] & 269 & $19.97 \pm 18.72$ \\
ESR [mm/hour] & 266 & $7.40 \pm 10.13$ \\
CRP [mg/L] & 266 & $20.01 \pm 35.10$ \\
Glucose [mg/dl] & 266 & $90.33 \pm 8.05$ \\
\hline
\end{tabular}

n; Number of patients, SD; Standard deviation, WBC; White blood cell , ANC; Absolute neutrophil count ALC; Absolute Lymphocyte Count , PC; Platelet count, AST; Aspartate Aminotransferase, ALT; Alanine Aminotransferase, ESR; Erythrocyte Sedimentation Rate, CRP; C Reactive Protein

\section{Discussion}

Gastroenteritis is a common disease in childhood all over the world, especially in developing countries. Various bacterial, viral and parasitic agents are blamed for the etiology of acute gastroenteritis. In our study, the distribution of the detected factors according to gender, age, month and seasons in 0-18 age group children diagnosed with acute gastroenteritis in the pediatric emergency department was evaluated.

Although AGE can be seen in all age groups in children, it is more common in younger ages. In the study of Karadag et al., $43.70 \%$ of AGE cases were reported to be children under 2 years old [6]. In the study of Gurbuz et al., $71.10 \%$ of the patients hospitalized due to AGE were reported to be children under 2 years old [7]. In our study in accordance with the literature, the median age of the patients was found to be 21 [0-170] months.

The frequency of infectious agents causing gastroenteritis may differ regionally and seasonally. Ceyhan et al. reported that $69 \%$ of gastroenteritis cases in children were observed in spring and summer, and 31\% in autumn and winter [8]. In the study of Gurbuz et al., Rotavirus infections were found most frequently in April, while cases with amebiasis were reported most frequently in September [7]. In the study of Emiroglu et al., it was observed that the gastroenteritis cases caused by Rotavirus in Istanbul in 2009 were higher between December and May [9]. In our study, the applications were mostly seen in the autumn season with a rate of $35.33 \%$, while they were seen in the least spring season with a rate of $18.89 \%$. In our study, the most frequent season of AGE is autumn, which may have resulted from interregional season and climate differences.

Diarrhea is the most important sign of gastroenteritis. Diarrhea may be accompanied by abdominal pain, nausea, vomiting, anorexia, fever, weight loss, and one or more signs of dehydration. Coffin et al. reported that vomiting was the most common finding in diarrhea in children with gastroenteritis [10]. In the study of Ghssein et al. which investigated AGE factors in 0-10 years old children, it was found that 93.30\% of cases had diarrhea, $76.80 \%$ had fever and $71.20 \%$ had vomiting symptoms [11]. The results of our study were determined similar to the literature.

In a study conducted by Charles et al., Hospitalization time of children under 5 years of age due to AGE was found to be 4.8 days on average [12]. In another study, the mean length of hospital stay was found between 2-9.5 days due to AGE [13]. In our study, it was found that 7.10\% of patients were treated inpatient and the mean length of hospitalization was $3.34 \pm 2.19$ days, similar to the literature.

According to the study of Brunser et al., The agent can be determined in 30-65\% of patients admitted due to AGE [14]. In the study conducted by Gurbuz et al., 57.70\% of AGE cases were found to have agents causing diarrhea, while $42.30 \%$ of them could not be detected [7]. However, in a study conducted by Friesema et al., it was found as one or more pathogen agents in $98 \%$ of the cases [15]. In this study, more than one agent was detected in $40 \%$ of cases, $82 \%$ virus, $32 \%$ bacteria, and $10 \%$ parasite. In addition, in a study conducted by Nicholson et al., it was reported that agents were detected in $70.40 \%$ of patients diagnosed with AGE and more than one factor was detected in $22.70 \%$ of cases [16]. In another study, Chen et al. reported that they detected $51.20 \%$ virus, $13.40 \%$ bacteria, and $7.30 \%$ bacteria and viruses together as AGE agents in hospitalized children [17]. In our study, $31.10 \%$ of the patients who applied with AGE were detected, while $68.90 \%$ did not find any agent. In cases where the agent were determined, $82.20 \%$ virus, $15.70 \%$ parasite and $2.10 \%$ bacteria were detected as the agents. In the patients we included in our study, only viruses were examined for Rotavirus and Adenovirus. For the detection of parasites, only microscopic examination was done, other tests were not performed. In addition, due to the limited bacteriological examinations, a limited number of bacteria could be studied. In our study, the lower rate of cases where the factor could not be determined compared to the studies in the literature may be related to different laboratory facilities in different centers.

Rotavirus is the most common cause of acute gastroenteritis in children globally [1]. Rotavirus infections, which are the cause of many epidemics, are more common in newborns and children under 5 years of age. In the study of Parashar et al., Rotavirus was found as an agent in acute gastroenteritis requiring hospitalization in children under 2 years of age in 2011, according to data from 184 regions from 64 countries [18]. In a study conducted by Berk et al. Rotavirus was found to be a factor in $27.80 \%$ of patients diagnosed with AGE [19]. In the study of Celik et al., the frequency of Rotavirus infection was reported to be $39.60 \%$ in patients with AGE [20]. Chen et al. found that the most common virus among AGE agents in children was Rotavirus and $35.40 \%$ among all gastroenteritis cases [17]. In the same study, the most common virus after rotavirus, Norovirus, was detected with a frequency of $29.30 \%$. In our study, in accordance with the literature, it was determined that viruses were the cause of $25.60 \%$ of the cases. The rate of viruses among the cases determined to be effective was $82.20 \%$. The most common pathogen was Rotavirus. Rotavirus was found in $22.70 \%$ of all cases and agent was found to be $72.90 \%$ among cases. 
In a study conducted by Kazi et al., $87 \%$ of patients with Rotavirus were shown to be under 2 years old and $61 \%$ were under one year old [21]. In another study, Bozdayi et al. reported that more than $70 \%$ of Rotavirus infections occur in children under 2 years old and 39\% under one year old [22]. Kocak et al. reported the mean age of children who received inpatient treatment for AGE and who had Rotavirus as an agent, as $13 \pm 8$ months [23]. In our study, the median age of patients with Rotavirus was found to be 17 [0-157] months, similar to the literature. $66.70 \%$ of the cases were patients younger than 2 years old.

In our study, it was observed that Rotavirus was less in summer than in winter. Bulut et al. reported that Rotavirus was seen as a gastroenteritis agent at $40 \%$ in winter and $8 \%$ in summer [24]. In another study, Berk et al. found the rate of rotavirus positivity in children with acute gastroenteritis $38.40 \%$ in winter and $12.30 \%$ in summer [19]. In accordance with the data in the literature, our study also shows that Rotavirus is seen more frequently in winter than in summer in our country.

Rotavirus is the most common etiological agent worldwide, especially in diarrhea under the age of 5 and hospital admissions related to it [7] [25]. Another common viral pathogen is enteric Adenoviruses. In our study, it is seen that Adenoviruses are in the third place as AGE agents with a rate of $2.90 \%$ among the total cases and $9.30 \%$ among those determined. In the study of Altindis et al., the frequency of enteric Adenovirus in children with acute diarrhea was $4.50 \%$ [26]. In the study of Karagun et al., Rotavirus frequency was $25.9 \%$, Adenovirus frequency was $8.4 \%$, and Rotavirus and Adenovirus association rate was $1.9 \%$ [27]. In our study, the incidence of Adenovirus in children with AGE was found to be similar to the literature.

Bacterial pathogens in developed countries are detected many cases of acute gastroenteritis, but these rates are higher in developing or undeveloped countries [1]. The incidence of bacterial agents that cause diarrhea in our country has been reported at rates ranging from 5.70-30.60\% [28]. In our study, bacteria were detected as $0.60 \%$ among all cases and $2.10 \%$ among cases in which the factor was determined. Salmonella, Klebsiella and E.coli are bacteria identified as causative agents. In our study, bacterial pathogens were found to be relatively low. The reason for this may be the development level and hygienic conditions of Konya region where the study is conducted. In addition, the limited bacteriological examinations in children with AGE may have led to this result.

In the study of Yapici et al., parasites were detected in 39\% of children, among them, it was reported that Giardia intestinalis was found $15 \%$, E.vermicularis $10 \%$, and E. Histolytica $0.25 \%$ [29]. In studies in the literature, the most common parasite detected in patients with AGE is Giardia intestinalis. In our study, there was no case with Giardia as the agent. This result may be due to the fact that Giardiasis performed more persistent diarrhea in children and that only one stool sample was taken from our patients and only microscopic examination was performed in the sample.

In the study of Erdogan et al., while ALT and AST values were higher in patients with positive Rotavirus test, no significant difference was found in terms of WBC, PLT, PCT, MPV and CRP values [30]. The results of our study were similar to those in the literature. This result may be related to the insignificance of blood tests in the differential diagnosis of the factors.

\section{Limitations}

There are some limitations in our study. Our study contains only data from our region since it is single-centered. This situation reduces the possibility of the results we obtained in the study to reflect the whole society. In addition, the insufficiency of methods for detecting agents is seen as a limitation of our study.

\section{Conclusion}

As a result, diarrheal diseases are important in terms of malnutrition and growth-development in children, as well as causing dehydration and death. Empirical use of antibiotics in the treatment of acute gastroenteritis can lead to an increase in the cost of treatment, antibiotic resistance in microorganisms and side effects in patients. Therefore, determining the agent and giving appropriate treatment is very important.

\section{Recommendations for future research}

More randomized controlled studies should be conducted regarding the regional distribution of agents causing acute gastroenteritis in children.

\section{Conflict of interest: None}

\begin{tabular}{|c|r|l|}
\hline \multicolumn{2}{|c|}{ Author Contributions } & \multicolumn{1}{c|}{ Author Initials } \\
\hline SCD & Study Conception and Design & H.M.H.A, A.Y. \\
\hline AD & Acquisition of Data & H.M.H.A \\
\hline AID & Analysis and Interpretation of Data & A.O.K., H.M.H.A \\
\hline DM & Drafting of Manuscript & A.O.K, H.M.H.A., A.Y, F.A \\
\hline CR & Critical Revision & A.O.K, A.Y., F.A. \\
\hline
\end{tabular}

Financial support: None

\section{References}

1. Kotloff KL. Acute Gastroenteritis in Children. In: Kliegman RM, St. Geme III JW, Blum NJ, Shah SS, Tasker RC, Wilson KM, editors. Nelson Textbook of Pediatrics. 21st ed. Philadelphia: Elsevier; 2020. p. 2012-32.

2. Tekin M, Topaloglu N, Yildirim S, Binnetoglu K, Kaymaz N, Aylanc H, et al. Frequency of Rotavirus in children with acute gastroenteritis. Int J Clin Res. 2014;2(1):18-20. 
3. Gill CJ, Thea DM, Hibberd P. Diarrhoeal disease trends in the GBD 2015 study: optimism tempered by scepticism. Lancet Infect Dis. 2017;17(9):884-5. https://doi.org/10.1016/S1473-3099(17)30336-5

4. Bialvaei AZ, Kafil HS, Asgharzadeh M, Aghazadeh M, Yousefi M. CTX-M extended-spectrum $\beta$-lactamase-producing Klebsiella spp, Salmonella spp, Shigella spp and Escherichia coli isolates in Iranian hospitals. Brazilian J Microbiol. 2016;47(3):706-11. https://doi.org/10.1016/j.bjm.2016.04.020

5. Kail R. Child and Their Development. Campanella C, editor. Pearson; 2011.

6. Karadag A, Acikgoz ZC, Avci Z, Catal F, Gocer S, Gamberzade S, et al. Childhood diarrhoea in Ankara, Turkey: Epidemiological and clinical features of rotavirus-positive versus rotavirus-negative cases. Scand J Infect Dis. 2005;37(4):269-75. https://doi.org/10.1080/00365540410020983

7. Gurbuz F, Tezer H, Sayli TV. Etiologic factors and clinical findings of patients hospitalized children for acute gastroenteritis: epidemiologic study. Turkish J Pediatr Dis 2010;4(4):211-8.

8. Ceyhan I, Cakir B, Cakir E, Tamkan S, Ozcay S. Pediatric acute gastroenteritis cases. [In Turkish] Medeniyet Med J 2002;634:11-2.

9. Emiroglu MK Salman M. Seroprevalence and clinical feature of Rotavirus gastroenteritis among hospitalized children under five years old in Istanbul [In Turkish]. Rumi Pediatrics Congress Proceeding Booklet 2019. p. 268-75. https://irupec.com/tr/bildirikitabi.pdf

10. Coffin SE, Elser J, Marchant C, Sawyer M, Pollara B, Fayorsey R, et al. Impact of acute rotavirus gastroenteritis on pediatric outpatient practices in the United States. Pediatr Infect Dis J 2006;25(7):584-9. https://doi.org/10.1097/01.inf.0000220251.27595.74

11. Ghssein G, Salami A, Salloum L, Chedid P, Joumaa WH, Fakih H. Surveillance study of acute gastroenteritis etiologies in hospitalized children in South Lebanon [SAGE study]. Pediatr Gastroenterol Hepatol Nutr 2018;21(3):176-83. https://doi.org/10.5223/pghn.2018.21.3.176

12. Charles MD, Holman RC, Curns AT, Parashar UD, Glass RI, Bresee JS. Hospitalizations associated with rotavirus gastroenteritis in the United States, 1993-2002. Pediatr Infect Dis J 2006;25(6):489-93. https://doi.org/10.1097/01.inf.0000215234.91997.21

13. Giaquinto C. The paediatric burden of rotavirus disease in Europe. Epidemiol Infect 2006;134(5):908-16. https://doi.org/10.1017/S0950268806006091

14. Brunser O, Espinoza J Brunser AM. Etiology of Diarrhea: Bacteria and parasites. Nestle Nutr Work Ser Lippincott-Raven comp 1997;(38):13-39. https://www.nestlenutrition-institute.org/resources/publication-series/publications/article/details/nniw38---diarrhealdisease/etiology-of-diarrhea-bacteria-and-parasites (Access Date: March 04, 2021)

15. Friesema IHM, De Boer RF, Duizer E, Kortbeek LM, Notermans DW, Norbruis OF, et al. Etiology of acute gastroenteritis in children requiring hospitalization in the Netherlands Eur J Clin Microbiol Infect Dis 2012;31(4):405-15. https://doi.org/10.1007/s10096-011-1320-0

16. Nicholson MR, Van Horn GT, Tang YW, Vinjé J, Payne DC, Edwards KM, et al. Using multiplex molecular testing to determine the etiology of acute gastroenteritis in children. J Pediatr 2016;176:50-56.e2. https://doi.org/10.1016/j.jpeds.2016.05.068

17. Chen SM, Ni YH, Chen HL, Chang MH. Microbial etiology of acute gastroenteritis in hospitalized children in Taiwan. J Formos Med Assoc 2006;105(12):964-70. https://doi.org/10.1016/S0929-6646(09)60280-1

18. Parashar U, Steele D, Neuzil K, Quadros C De, Tharmaphornpilas P, Serhan F, et al. Progress with rotavirus vaccines: Summary of the tenth international rotavirus symposium. Expert Rev Vaccines 2013;12(2):113-7. https://doi.org/10.1586/erv.12.148

19. Berk E, Kayman T. Frequency of Rotavirus in children with acute gastroenteritis [In Turkish]. Ankem J 2012;25(2):103-6. https://doi.org/10.5222/ankem.2011.103

20. Celik AY, Emiroglu M, Kurtoglu MG, Inci A, Odabas D. Investigation of the frequency of viral agents in children with acute gastroenteritis in the 0-5 years age group [In Turkish]. Turkish J Pediatr Dis 2016;(2):101-6.

21. Kazi AM, Khan MMA, Zaidi AKM, Akhter R, Aziz F, Billoo AG, et al. Sentinel hospital-based surveillance for assessment of burden of rotavirus gastroenteritis in children in Pakistan. PLoS One 2014;9(10): e108221. https://doi.org/10.1371/journal.pone.0108221

22. Bozdayi G, Dogan B, Dalgic B, Bostanci I, Sari S, Battaloglu NO, et al. Diversity of Human Rotavirus G9 among children in Turkey. J Med Virol 2008;(80):733-40. https://doi.org/10.1002/jmv.21120

23. Kocak M, Caliskan E, Koksal AO. Rotavirus frequency in children with acute gastroenteritis who were hospitalized in Kecioren Education and Research Hospital Pediatric Clinic. [In Turkish] Ankem J 2014;28(4):134-7. https://doi.org/10.5222/ankem.2014.134

24. Bulut Y, Iseri L, Agel E DB. The positivity of Rotavirus in children with suspected acute gastroenteritis. [In Turkish] J Med Faculty Inonu Univ 2003;10(3):143-5.

25. Jia L, Qian Y, Zhang Y, Deng L, Liu L, Zhu R, et al. Prevalence and genetic diversity of noroviruses in outpatient pediatric clinics in Beijing, China 2010-2012. Infect Genet Evol 2014;28:71-7. https://doi.org/10.1016/j.meegid.2014.09.006

26. Altındis M, Bastepe G, Ceri A, Yavru S, Kalayci R. Frequency of Rotavirus and Enteric Adenovirus infection in children with acute gastroenteritis. [In Turkish]. Med. J SDU 2008;15(2):17-20.

27. Karagun BS, Gursu HA, Korkmaz O, Bozdag I, Hasbek M. A Search for the incidence of acute gastroenteritis due to Rotavirus and Enteric Adenovirus in children under five years old. J Turk Mikrobiyol Cem 2015;44(2):70-4. https://doi.org/10.5222/TMCD.2014.070

28. Eroglu C. Approach to a patient with acute diarrhea. [In Turkish]. IU Cerrahpasa Faculty Med CME Act 2008;(61):171-8.

29. Yapici F, Tamer GS, Arisoy ES. The Distribution of intestinal parasites and their causative factors in children. [In Turkish]. J Turkish Parasite 2008;32(4):346-50.

30. Erdogan S, Yazar AS, Güven S, Durak U, Akova S. Serum transaminase elevation in patients with Rotavirus Gastroenteritis. [In Turkish] . J Clin Anal Med. 2017;8(6):488-91. https://doi.org/10.4328/JCAM.5225 